\title{
Supporting Information for: The Effect of Counterion on the Rate of Electron Transfer in Dendrimer Films
}

Tyson L. Chasse, Jennifer C. Smith, Richard L. Carroll and Christopher B. Gorman*

Department of Chemistry

North Carolina State University

Box 8204

Raleigh, NC 27695-8204

\section{Materials}

Chemicals. All solvents used in electrochemical experiments were anhydrous, purchased from Aldrich or Acros and stored under $\mathrm{N}_{2}$ atmosphere in a dry box. Tetramethylammonium (TMA), tetraethylammonium (TEA), and tetrabutylammonium (TBA) hexafluorophosphate salts were recrystallized three times from ethanol and stored under $\mathrm{N}_{2}$ atmosphere in a dry box. Sodium hexafluorophosphate $\left(\mathrm{NaPF}_{6}\right)$ was used as received from Acros. The generation three dendrimer $\left(\left(n \mathrm{Bu}_{4} \mathrm{~N}\right)_{2}\left[\mathrm{Fe}_{4} \mathrm{~S}_{4}(\mathrm{G} 3)_{4}\right]\right)$ was prepared as described previously. ${ }^{1}$

Tetraoctylammonium hexafluorophosphate was prepared by ion exchange chromatography using Amberlite ${ }^{\circledR}$ IRA $-400(\mathrm{OH})$ ion-exchange resin monitored by $\mathrm{pH}$ (pHydrion INSTA-CHEK 0-13 pH paper). 1.5g (1 equiv.) of resin was rinsed with

\footnotetext{
* To whom correspondence should be addressed. E-mail: chris_gorman@ncsu.edu.
} 
copious amounts of water. The $\mathrm{pH}$ of the water passed through was approximately 7 . Then, 37.5 mmol (10 equiv.) of aqueous $\mathrm{NaPF}_{6}(\mathrm{pH} \sim 1$ ) was injected into the column and allowed to soak for $1 \mathrm{hr}$. The solution was removed and the $\mathrm{pH}$ was determined to be approximately 4. This increase of $\mathrm{pH}$ indicates the presence of $\mathrm{NaOH}$ after ion exchange. The resin was rinsed with copious amounts of water to remove excess $\mathrm{NaOH}$ and $\mathrm{NaPF}_{6}$. The resin was then rinsed with copious amounts of methanol to remove excess water. Then $1 \mathrm{mmol}$ ( 0.27 equiv.) of tetraoctylammonium bromide in methanol was added to the column and allowed to soak for 1 hour (swirling occasionally to ensure complete exchange). The solution was removed and the resin rinsed with methanol to collect all remaining salt. The solution was evaporated to dryness using a rotatory evaporator. Yield: $85 \%(0.52 \mathrm{~g}) .{ }^{1} \mathrm{H}$ NMR $\left(\mathrm{CD}_{3} \mathrm{COCD}_{3}\right) \delta(300 \mathrm{MHz}): 0.86(\mathrm{t}, 12 \mathrm{H}, \mathrm{J}=6.6 \mathrm{~Hz}), 1.20$ - $1.47(\mathrm{~m}, 40 \mathrm{H}), 1.92-1.78(\mathrm{~m}, 8 \mathrm{H}), 3.47(\mathrm{~m}, 8 \mathrm{H})$. Anal. Calc. for $\mathrm{C}_{32} \mathrm{H}_{68} \mathrm{NPF}_{6}: \mathrm{C}$, 62.81; H, 11.19; N, 2.29. Found: C, 63.07; H, 11.27; N, 2.30.

Preparation of Films and Electrodes. A two millimolar concentration of $\left(n \mathrm{Bu}_{4} \mathrm{~N}\right)_{2}\left[\mathrm{Fe}_{4} \mathrm{~S}_{4}(\mathrm{G} 3)_{4}\right]$ dendrimer was dissolved in tetrahydrofuran. Pt disk working electrodes were polished, conditioned and referenced to a dendrimer standard previously studied within our group. ${ }^{1}$ Dendrimer films were drop-coated on the electrode surface with a $5 \mathrm{uL}$ drop of $2 \mathrm{mM}$ dendrimer/THF solution and allowed to dry for approximately 10 minutes. The Pt working electrode was then placed into a three electrode cell containing a solution of the desired electrolyte $(100 \mathrm{mM})$ in propylene carbonate $(\mathrm{PC}, \mathrm{a}$ non-solvent for the dendrimers studied). 


\section{Electrochemical Analysis.}

Apparatus. Electrochemical experiments were carried out on a Bioanalytical Systems CV-50W Voltammetric Analyzer. Chronoamperometry and cyclic voltammetry $(20 \mathrm{mV} / \mathrm{sec})$ measurements were carried out in a three-electrode cell consisting of a platinum disk working electrode with a geometric area of $0.0201 \mathrm{~cm}^{2}$, a Pt auxiliary electrode, and a homemade nonaqueous $\mathrm{Ag} / \mathrm{AgNO}_{3}$ reference electrode ( $\mathrm{Ag}$ wire contacting a MeCN solution of $0.01 \mathrm{M} \mathrm{AgNO}_{3}$ and $0.1 \mathrm{M}$ supporting electrolyte, tetrabutylammonium hexafluorophosphate (TBAH)). All electrochemical experiments were carried out in a nitrogen-filled Vacuum Atmospheres drybox at room temperature.

Film Thickness. was calculated as described previously. ${ }^{2}$

Electroanalysis of Films. This study was carried out in multiple electrolytes (TMA, TEA, TBA, and TOA) to compare kinetic information based on electrolyte size/polarity. The electrochemical experiments were carried out for the thin film in TOA. The electrode was then removed, rinsed with PC and immediately immersed in TBA followed by TEA and finally, TMA. This was repeated six times with two different Pt electrodes. The kinetic study was also carried out in reverse order from TMA to TEA, TBA and finally TOA. In each study, voltammetric pre-cycling was required to obtain a stable response. This was done for each thin film until a stable response was reached where upon data was collected. No dissolution of the films was visibly evident due to the molecules being highly colored and obvious when solvated. All data was further analyzed as described previously. ${ }^{2}$ 


\section{References}

(1) Gorman, C. B., Smith, J. C., Hager, M. W., Parkhurst, B. L., Sierzputowska-

Gracz, H., Haney, C. A. J. Am. Chem. Soc. 1999, 121, 9958-9966.

(2) Gorman, C.B.; Smith, J. C. J. Am. Chem. Soc. 2000, 122, 9342-9343. 